\title{
Regulation of nitrogen metabolism in the marine diazotroph Trichodesmium IMS101 under varying temperatures and atmospheric $\mathrm{CO}_{2}$ concentrations
}

Orly Levitan, ${ }^{1}$ Christopher M. Brown, ${ }^{2 \dagger}$

Stefanie Sudhaus, ${ }^{3}$ Douglas Campbell, ${ }^{2}$

Julie LaRoche ${ }^{3}$ and Ilana Berman-Frank ${ }^{1 *}$

${ }^{1}$ The Mina and Everard Goodman Faculty of Life

Sciences, Bar Ilan University, Ramat Gan, 52900, Israel.

${ }^{2}$ Department of Biology, Mount Allison University,

Sackville, NB E4L 1G7, Canada.

${ }^{3}$ IFM-GEOMAR, Leibniz Institute of Marine Sciences at

Kiel University, 24105 Kiel, Germany.

\section{Summary}

We examined the influence of forecasted changes in global temperatures and $p \mathrm{CO}_{2}$ on $\mathrm{N}_{2}$ fixation and assimilation in the ecologically important cyanobacterium Trichodesmium spp. Changes of mRNA transcripts (nifH, gInA, hetR, psbA, psaB), protein (nitrogenase, glutamine synthetase) pools and enzymatic activity (nitrogenase) were measured under varying $p \mathrm{CO}_{2}$ and temperatures. High $p \mathrm{CO}_{2}$ shifted transcript patterns of all genes, resulting in a more synchronized diel expression. Under the same conditions, we did not observe any significant changes in the protein pools or in total cellular allocations of carbon and nitrogen (i.e. $\mathrm{C}: \mathrm{N}$ ratio remained stable). Independently of temperature, high $\mathrm{pCO}_{2}(900 \mu \mathrm{atm})$ elevated $\mathrm{N}_{2}$ fixation rates. Levels of the key enzymes, nitrogenase and glutamine synthetase that mediate nitrogen assimilation did not increase, implying that the high $\mathrm{pCO}_{2}$ allowed higher reaction turnover rates through these key enzymes. Moreover, increased temperatures and high $\mathrm{pCO}_{2}$ resulted in higher $\mathrm{C}: \mathrm{P}$ ratios. The plasticity in phosphorous stoichiometry combined with higher enzymatic efficiencies lead to higher growth rates. In cyanobacteria photosynthesis, carbon uptake, respiration, $\mathrm{N}_{2}$ fixation and nitrogen assimilation share cellular components. We propose that shifted cellular resource and energy allocation among those components will

Received 29 June, 2009; accepted 22 January, 2010. *For correspondence. E-mail irfrank@mail.biu.ac.il; Tel. (+972) 3 5318214; Fax (+972) 3 5318214. 'Present address: Institute of Marine and Coastal Sciences, School of Environmental and Biological Sciences, Rutgers University, New Brunswick, NJ 08901, USA. enable Trichodesmium grown at elevated temperatures and $p \mathrm{CO}_{2}$ to extend its niche in the future ocean, through both tolerance of a broader temperature range and higher $P$ plasticity.

\section{Introduction}

Key phytoplankton species contributing to oceanic primary production and global biogeochemical nutrient cycles may be significantly affected by oceanic acidification and the global increases in temperatures and atmospheric $\mathrm{pCO}_{2}$. One such species is the marine nitrogen-fixing (diazotroph) cyanobacterium Trichodesmium spp. contributing $25-50 \%$ of the geochemically derived rates of $\mathrm{N}_{2}$ fixation in various ocean basins, especially in the oligotrophic tropical and subtropical oceans (Capone and Subramaniam, 2005; Mahaffey et al., 2005). Trichodesmium forms extensive surface blooms that stimulate the biogeochemical cycling of carbon and nitrogen in an area corresponding to almost half of the Earth's surface (Davis and McGillicuddy, 2006; Carpenter and Capone, 2008).

The impacts of enhanced $\mathrm{pCO}_{2}$ on Trichodesmium IMS101 have been actively investigated. Increased $\mathrm{pCO}_{2}$ stimulated rates of $\mathrm{N}_{2}$ fixation and supported higher growth rates and biomass accumulation (Hutchins et al., 2007; Levitan et al., 2007; Ramos et al., 2007). Elevated sea surface temperature (SST) may further extend Trichodesmium's spatial distribution and hence its importance in the nitrogen cycle at higher latitudes (Breitbarth et al., 2007). Preliminary studies show further enhancement of $\mathrm{N}_{2}$ fixation and growth under combined high $\mathrm{pCO}_{2}$ and warmer temperatures (Hutchins et al., 2007). Yet, to our knowledge, the mechanisms underlying these phenomena are unknown.

Nitrogen fixation is expensive, requiring substantial investments in cellular energy, reductant and material resources. Cyanobacterial diazotrophs must separate the antagonistic processes of $\mathrm{N}_{2}$ fixation and oxygenic photosynthesis to avoid the inhibition of the nitrogenase enzyme by oxygen. Moreover, photosynthetic carbon fixation supplies organic skeletons as substrates for nitrogen assimilation. In many aquatic photosynthesizing organisms intracellular carbon concentrating mechanisms 
(CCM) provide and maintain adequate $\mathrm{CO}_{2}$ concentrations around RubisCo, thus mitigating limitations due to the generally low availability of ambient $\mathrm{CO}_{2}(\mathrm{aq})$ in seawater (Raven, 1997; Tortell et al., 2000; Badger et al., 2006).

Genomic analysis of Trichodesmium (http://genome. jgi-psf.org/finished_microbes/trier/trier.home.html) reveals that Trichodesmium IMS101 lacks known high affinity uptake complexes for $\mathrm{Ci}$, suggesting that Trichodesmium IMS101 might respond strongly to changes in $\mathrm{pCO}_{2}$. Yet, Trichodesmium IMS101 uses the abundant $\mathrm{HCO}_{3}{ }^{-}$in seawater for over $90 \%$ of its inorganic carbon uptake under varying $\mathrm{pCO}_{2}$ concentrations (Kranz et al., 2009). Considering the steady availability of its major dissolved inorganic carbon (DIC) source, $\mathrm{HCO}_{3}{ }^{-}$, under projected $\mathrm{pCO}_{2}$ levels, it is surprising that Trichodesmium responds to an increase in $\mathrm{pCO}_{2}$ with enhanced $\mathrm{N}_{2}$ fixation and growth (Levitan et al., 2007).

$\mathrm{N}_{2}$ fixation is regulated at the transcriptional, posttranscriptional and post-translational levels (Capone et al., 1990; Zehr et al., 1993; Chen et al., 1998; 1999). Nitrogenase synthesis and activity in Trichodesmium spp. typically exhibit a diel cycle, with nitrogenase activity confined to the photoperiod by a complex spatial and temporal strategy that allows nitrogenase and photosynthesis to operate concurrently during the photoperiod (Lin et al., 1998; Chen et al., 1999; Mulholland and Capone, 1999; Berman-Frank et al., 2001a; Küpper et al., 2004).

The highest rates of $\mathrm{N}_{2}$ fixation occur around midday in parallel with peak mRNA transcript abundance for nifH, the gene encoding the $\mathrm{Fe}$ protein subunit $(\mathrm{NifH})$ of the nitrogenase (Chen et al., 1999). The nitrogenase holoenzyme is synthesized each morning via an increase in the expression of the nifHDK operon (Capone et al., 1990; Chen et al., 1998). The assembly of nitrogenase is complex, involving the products of the core subunit nifHDK genes along with products from additional genes located within the nif operon (Raymond et al., 2004). Nitrogenase comprises two subunits, the MoFe dinitrogenase protein and the dinitrogenase reductase $\mathrm{Fe}$ protein, which are encoded by the nifHDK operon (Zehr et al., 1991). The MoFe protein is a tetramer of two NifD $(\alpha)$ and two NifK $(\beta)$ subunits. The $\alpha \beta$ pairs are functionally equivalent dimers, each of which binds molecular nitrogen and reduces it to ammonia. The Fe protein, also called the nitrogenase reductase, is the obligate electron donor to the MoFe protein, and is a homodimer formed by two $\mathrm{NifH}$ $(\gamma)$ subunits. The Fe protein is synthesized and degraded daily, with the levels of active $\mathrm{NifH}$ protein corresponding roughly to nitrogenase activity (Zehr et al., 1993). The metabolic signals causing the modification and concomitant activation of the nifH gene and the nitrogenase protein biosynthesis are not yet known (Zehr et al., 1993; Mulholland and Capone, 2000).
The $\mathrm{NH}_{4}{ }^{+}$generated by nitrogenase activity in Trichodesmium spp. is assimilated via the glutamine synthetase/glutamate synthase (GS/GOGAT) pathway (Carpenter et al., 1992; Kramer et al., 1996; Mulholland and Capone, 2000). In field samples of T. thiebautii, glutamine synthetase (GS) transcript levels increased to a maximum in the afternoon during the period of maximum $\mathrm{N}_{2}$ fixation (Kramer et al., 1996), while GS activity remained steady throughout the diel cycle (Carpenter et al., 1992). A positive correlation between the abundance of GS protein and the nitrogenase enzyme was observed in Trichodesmium spp. (Carpenter et al., 1992). Moreover, GS was suggested to play an important regulatory role in $\mathrm{N}_{2}$ fixation either directly or indirectly, by preventing feedback inhibition from accumulated metabolites (Flores and Herrero, 1994; Mulholland and Capone, 2000).

Diazotrophs, especially non-heterocystous diazotrophs such as Trichodesmium spp., are metabolically and ecologically restricted by the direct and indirect energetic demands of $\mathrm{N}_{2}$ fixation. Moreover, the complexity of the co-occurring energy producing processes of photosynthesis and respiration, and the energy consuming processes of CCM, carbon fixation, anti-oxidant activities and $\mathrm{N}_{2}$ fixation, require tight coupling and regulation of energy and resource allocation. Accordingly, these resources may be reallocated and their regulation modified (Levitan et al., 2007) to allow for the higher $\mathrm{N}_{2}$ fixation and growth rates demonstrated at higher $\mathrm{pCO}_{2}$ and temperatures in Trichodesmium (Hutchins et al., 2007).

To elucidate the mechanisms underlying Trichodesmium's response to the combined changes in $\mathrm{pCO}_{2}$ and temperature, we grew Trichodesmium IMS101 at varying $\mathrm{pCO}_{2}\left(250,400\right.$ and $\left.900 \mu \mathrm{atm} p \mathrm{CO}_{2}\right)$ and temperatures $\left(25^{\circ} \mathrm{C}\right.$ and $\left.31^{\circ} \mathrm{C}\right)$, and examined key metabolic processes and diel changes in transcript, protein and activity levels related to nitrogen fixation and assimilation.

\section{Results}

\section{Growth rates and $C, N, P$ stoichiometry}

Temperature and $\mathrm{pCO}_{2}$ co-affected the cultures, with $900 \mu \mathrm{atm} / 31^{\circ} \mathrm{C}$ cultures having the highest growth rates, consistent with previous studies (Hutchins et al., 2007; Levitan et al., 2007). In cultures grown at $400 \mu \mathrm{atm} / 25^{\circ} \mathrm{C}$ (control treatment) the growth rates were $0.17 \pm 0.04$ day $^{-1}$. Growth rates increased by $51 \%$ under $250 \mu \mathrm{atm} /$ $31^{\circ} \mathrm{C}$ relative to the control but were not significantly different according to Scheffe post hoc test. The temperature contribution yielded a significant increase of growth rates and increased by $58 \%$ under $400 \mu$ atm (reaching $0.27 \pm 0.01 \mathrm{~d}^{-1}$ ). Both $900 \mu \mathrm{atm}$ acclimations were significantly different from the control. At $31^{\circ} \mathrm{C}$ the increase in 


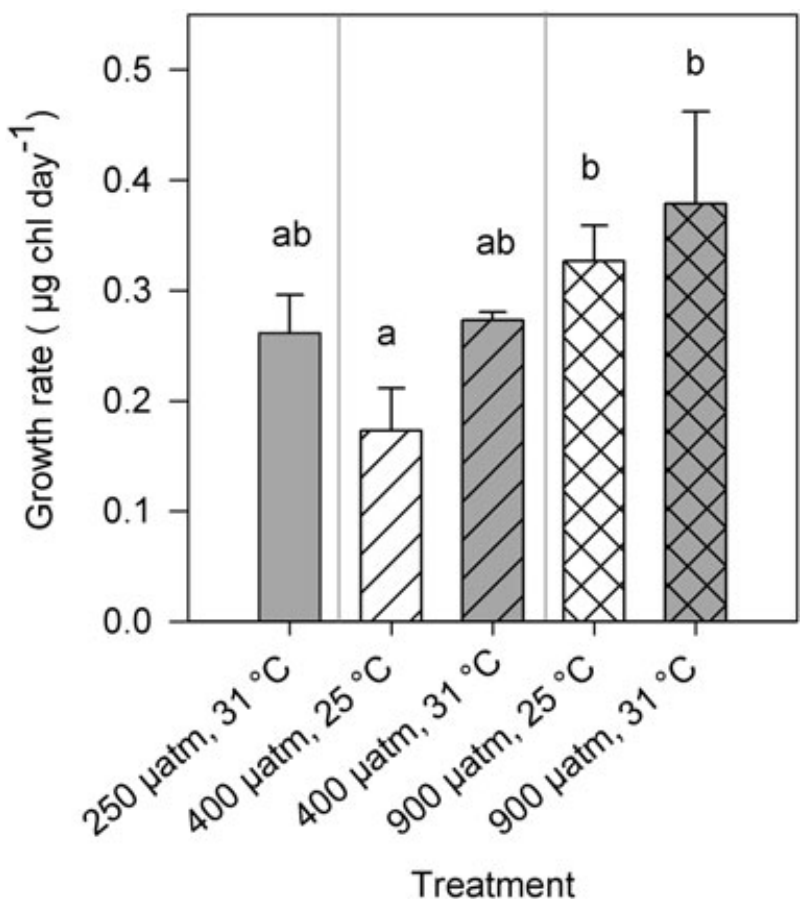

Fig. 1. Exponential growth rates of Trichodesmium IMS101 under a matrix of $p \mathrm{CO}_{2}(250,400$ and $900 \mu \mathrm{atm})$ and temperatures $\left(25^{\circ} \mathrm{C}\right.$ and $31^{\circ} \mathrm{C}$ ). Open bars: $25^{\circ} \mathrm{C}$, grey bars: $31^{\circ} \mathrm{C}$. Values represent treatment average ( $n=3$ or 4$)$. Errors are \pm 1 standard deviation. Average values are significantly different according to both Kruskal-Wallis Test $(p<0.05)$ and to one-way ANOVA $(p<0.05)$. Different letters represent significant difference between groups according to Scheffe post hoc test.

growth rates between 400 and $900 \mu$ atm was 15\% (from $0.33 \pm 0.03$ to $0.38 \pm 0.08)$ but was not entirely significant (Fig. 1).

We did not resolve distinct patterns in the cellular stoichiometry of $\mathrm{C}, \mathrm{N}$ or $\mathrm{P}$ during the photoperiod (data not shown) for any of the treatments. $\mathrm{C}: \mathrm{N}$ values were significantly different between the control and the $250 / 31^{\circ} \mathrm{C}$ and $900 / 31^{\circ} \mathrm{C}$ treatments (one-way ANOVA, $p<0.05$, Scheffe post hoc test). However, the mean $\mathrm{C}: \mathrm{N}$ ratio for all samples was $6.53 \pm 0.75\left(R^{2}=0.91, n=61\right.$, Fig. $\left.2 A\right)$. Although the data exhibited partially significant differences among the treatments, this was due to statistical test on a large number of independent replicates, and is not physiologically meaningful. The mean value of $6.53 \pm 0.75$ approximates the 6.6 (Redfield) $\mathrm{C}: \mathrm{N}$ ratio and accords well with literature values of $5.6 \pm 0.35$ for cultured Trichodesmium across a range of steady-state growth rates (Holl and Montoya, 2008) and with the 4.7-7.3 range reported by LaRoche and Breitbarth (2005).

While $\mathrm{C}: \mathrm{N}$ remained relatively constant, the cellular $C: P$ ratios varied significantly between treatments (one-way ANOVA, $\mathrm{p}<0.05$, Scheffe post hoc test). All cultures were grown at replete $P$ concentrations, yet

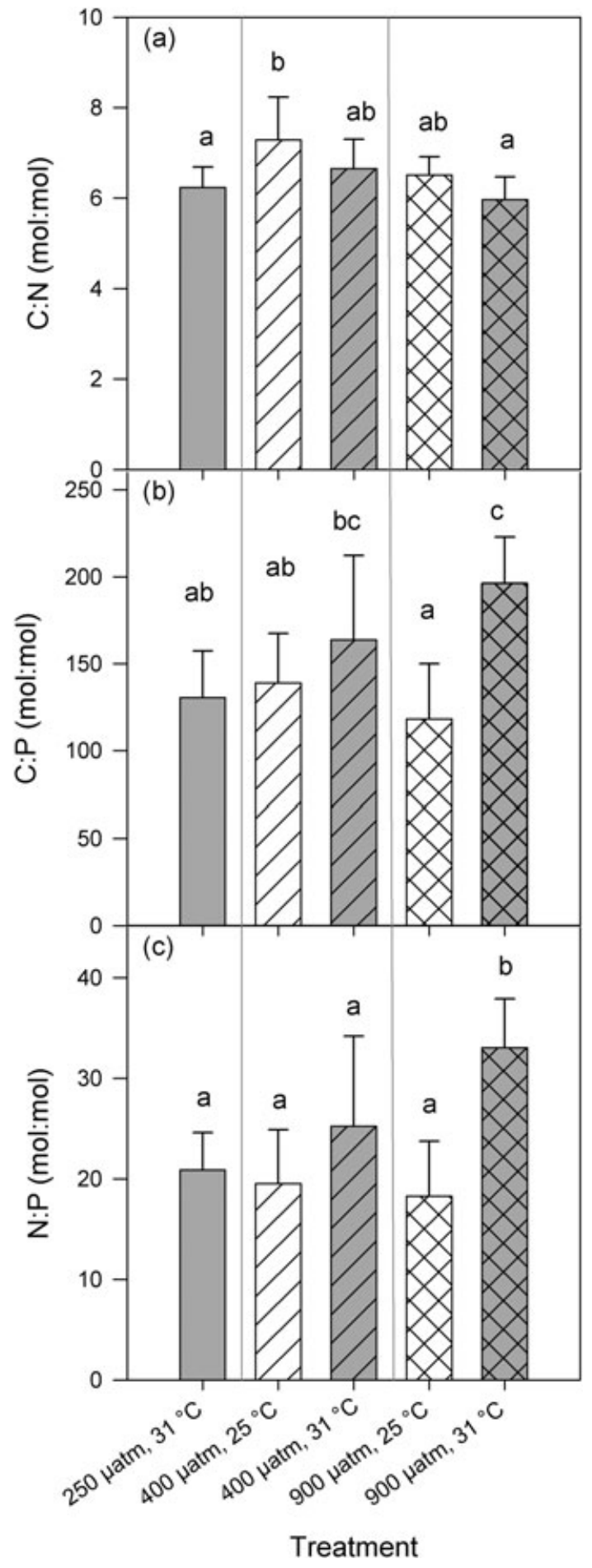

Fig. 2. Stoichiometric composition (mol: mol) of Trichodesmium IMS101 under a matrix of $p \mathrm{CO}_{2}$ and temperatures. (A) Carbon: Nitrogen $(C: N)$ ratio, $(B)$ Carbon: Phosphorus $(C: P)$ ratio and $(C)$ $\mathrm{N}$ : $\mathrm{P}$ ratio. Open bars: $25^{\circ} \mathrm{C}$, grey bars: $31^{\circ} \mathrm{C}$. Stoichiometric ratios are presented by treatments $(n=12-13)$. Errors are \pm 1 standard deviation. Significance between groups was determined by one-way ANOVA $(p<0.001)$ followed by a Scheffe post hoc test. According to Scheffe post hoc test $p<0.001$ for $C: N$ averages, $\mathrm{p}<0.05$ for $\mathrm{C}: \mathrm{P}$ averages and $\mathrm{p}<0.001$ for $\mathrm{N}: \mathrm{P}$ averages. Different letters represent significant difference between groups. 
$\mathrm{C}: \mathrm{P}$ ratios exhibited temperature dependency at both 400 and particularly at $900 \mu \mathrm{atm}$ (Fig. 2B). Cultures grown at $400 \mu$ atm increased their $\mathrm{C}: \mathrm{P}$ ratio by $18 \%$ (from $139 \pm 28$ at $25^{\circ} \mathrm{C}$ to $167 \pm 48$ at $31^{\circ} \mathrm{C}$ ) with the increase of temperature. The impact of temperature on elemental stoichiometry of $\mathrm{C}: \mathrm{P}$ was more pronounced under $900 \mu \mathrm{atm}$, where elevated temperatures significantly increased the C : $\mathrm{P}$ ratio by $66 \%$ (from $118 \pm 32$ at $25^{\circ} \mathrm{C}$ to $196 \pm 27$ at $31^{\circ} \mathrm{C}, \mathrm{mol}: \mathrm{mol}$ ) (Fig. 2B). Only the $\mathrm{N}: \mathrm{P}$ ratios of our 'greenhouse' $\left(900 \mu \mathrm{atm} / 31^{\circ} \mathrm{C}\right)$ treatment were significantly higher $(\sim 33)$ than all others (one-way ANOVA, $p<0.05$, Scheffe post hoc test), where the $\mathrm{N}: \mathrm{P}$ values were closer to the Redfield ratio of 16 .

\section{$\mathrm{N}_{2}$ fixation - transcript level, protein abundance and nitrogenase activity}

We examined the Fe protein of the nitrogenase at different levels: the nifH mRNA transcript levels, the NifH protein subunit abundance, and the enzymatic activity of the nitrogenase at several points during the photoperiod (Fig. 3).

The diel trends in the mRNA transcript levels were influenced by $\mathrm{pCO}_{2}$ levels. For comparisons of the nifH enrichment factor across growth treatments and measurement times (in Fig. 3A), we normalized transcript levels to the value of the early morning measurements of the ambient, $400 \mu \mathrm{atm} / 25^{\circ} \mathrm{C}$ treatment (control). Under low $(250 \mu \mathrm{atm})$ and ambient $(400 \mu \mathrm{atm}) \mathrm{pCO}_{2}$, at both $25^{\circ} \mathrm{C}$ and $31^{\circ} \mathrm{C}$, the nifH transcripts abundance followed the typical diel activity pattern of $\mathrm{N}_{2}$ fixation for Trichodesmium (as presented in Fig. $3 \mathrm{C}$ ) with a maximum abundance matching the midday peak in $\mathrm{N}_{2}$ fixation rates. At high $\mathrm{pCO}_{2}(900 \mu \mathrm{atm})$ this typical midday peak was shifted earlier, with nifH mRNA measured abundance highest at $1 \mathrm{~h}$ into the photoperiod and declined thereafter (Figs $3 \mathrm{~A}$ and $4 \mathrm{~A}$ ). For all treatments, transcript levels declined to minimal levels by the end of the photoperiod.

Nitrogenase enzyme abundance, estimated by quantitative immunodetection of the $\mathrm{NifH}$ subunit of the $\mathrm{Fe}$ protein (Fig. 3B), followed a diel trend in the $31^{\circ} \mathrm{C}$ cultures, similar to that previously found for the NifD subunit of the MoFe protein (Chen et al., 1998). We did not resolve a diel trend for $\mathrm{NifH}$ protein abundance in the $25^{\circ} \mathrm{C}$ cultures, despite a strong diel pattern in nitrogen fixation (Fig. $3 \mathrm{C}$ ). At the height of $\mathrm{N}_{2}$ fixation, from 5 to $9 \mathrm{~h}$ of the photoperiod, $\mathrm{NifH}$ protein abundance was approximately $274 \pm 96$ pmol $\mu \mathrm{g}$ total protein ${ }^{-1}, n=13$ across all growth treatments, irrespective of the differences in nitrogenase activity.

Nitrogenase activity was measured using the acetylene reduction assay as a proxy for nitrogen fixation (Fig. 3C). Consistent with previous observations (Hutchins et al.,

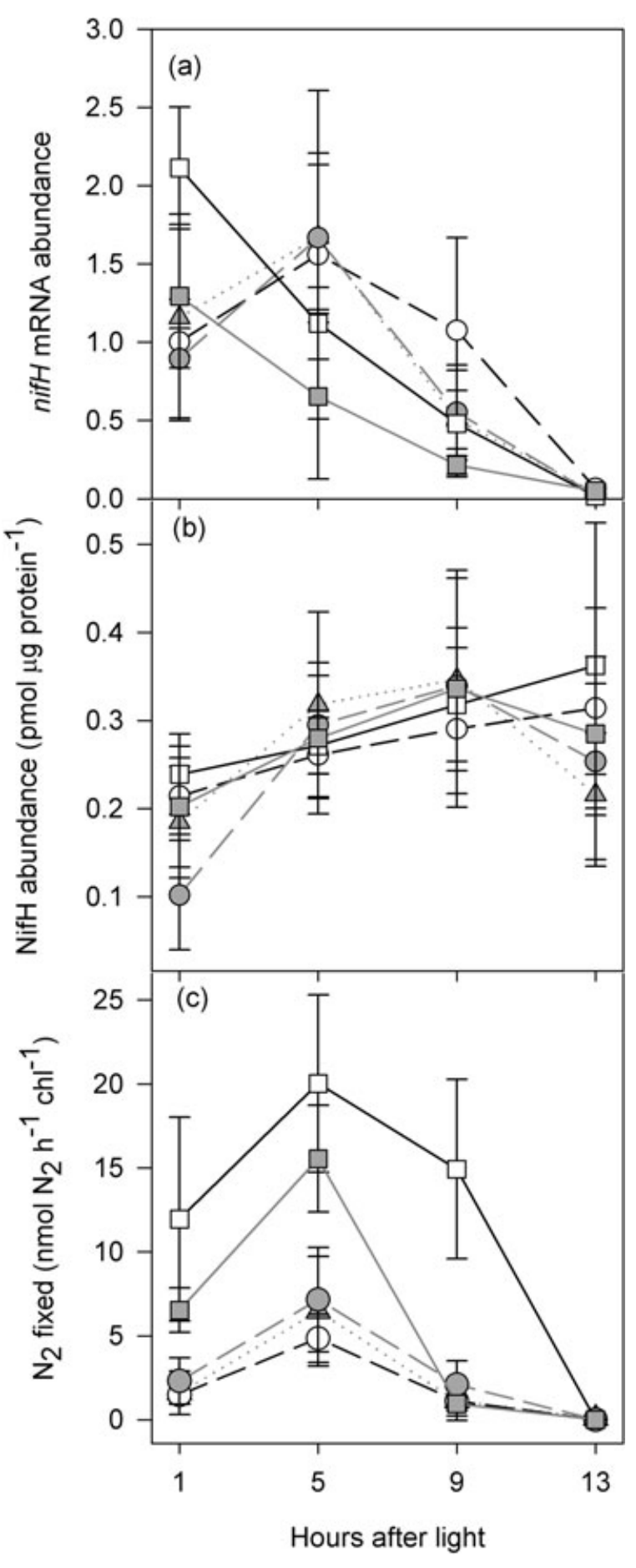

Fig. 3. Temporal changes in nifH, NifH and nitrogen fixation for Trichodesmium IMS101 under a matrix of $\mathrm{pCO}_{2}$ and temperatures. A. nifH mRNA transcript levels estimated according to the $2^{-\Delta \Delta \mathrm{Ct}}$ method, with 16s rRNA as the endogenous reference gene and the $\Delta \mathrm{Ct}$ values of the $\mathrm{GOI}$ from the control treatment at $1 \mathrm{~h}$ after illumination, as the calibrator.

B and C. (B) NifH protein amount (pmol $\mu$ g total protein ${ }^{-1}$ ) and (C) Rate of $\mathrm{N}_{2}$ fixation ( $\mathrm{nmol} \mathrm{N}_{2}$ fixed $\mathrm{h}^{-1} \mu \mathrm{g} \mathrm{chl}^{-1}$ ). Open symbols and black lines are for $25^{\circ} \mathrm{C}$, grey symbols and grey lines represent $31^{\circ} \mathrm{C}$. Squares: $900 \mu \mathrm{atm} p \mathrm{CO}_{2}$; circles: $400 \mu$ atm $p \mathrm{CO}_{2}$; triangles: $250 \mu \mathrm{atm} p \mathrm{CO}_{2} . n=3$ for all. Errors are \pm 1 standard deviation. 

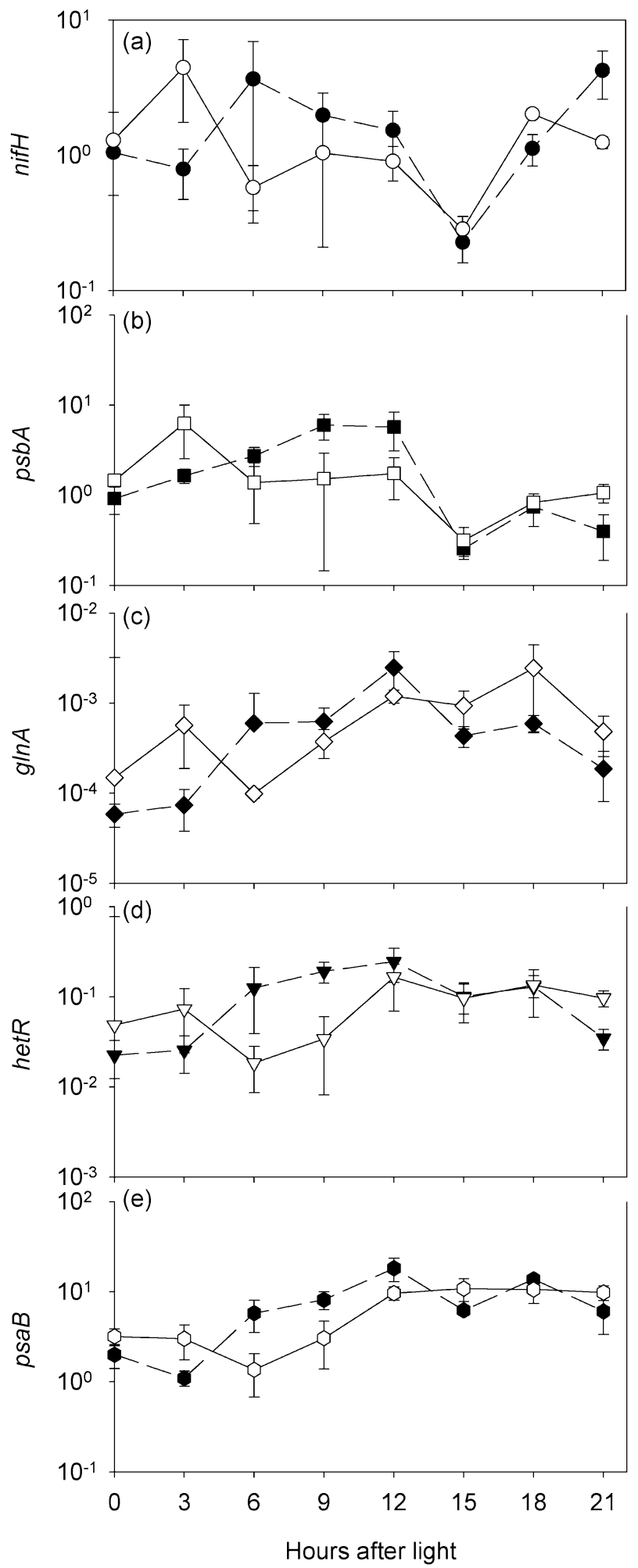

2007; Levitan et al., 2007; Ramos et al., 2007), nitrogenase activity was two- to fivefold higher in the $900 \mu \mathrm{atm}$ $p \mathrm{CO}_{2}$ treatments than at 400 and $250 \mu$ atm $p \mathrm{CO}_{2}$. For all treatments, nitrogen fixation followed a clear diel pattern,
Fig. 4. Diel cycles of mRNA transcripts of five genes for Trichodesmium IMS101 under $400 \mu$ atm $p \mathrm{CO}_{2}$ and $900 \mu$ atm $p \mathrm{CO}_{2}$ (both under $25^{\circ} \mathrm{C}$ ). (A) nifH, encodes for $\mathrm{Fe}$ protein of nitrogenase, (B) $p s b A$, encodes for D1 subunit of photosystem I, (C) $g \ln A$, encodes for glutamine synthetase, (D) hetR encodes a key element in cyanobacteria nitrogen related metabolism, and is involved in regulation of heterocysts, and in nitrogen fixation pathways in Trichodesmium, (E) psaB encodes for a photosystem I subunit. Black symbols and dash lines $-400 \mu$ atm, open symbols and solid lines - $900 \mu \mathrm{atm}$. Relative abundance estimated according to the $2^{-\triangle \Lambda C T}$ method, with $16 \mathrm{~S}$ rRNA as the endogenous reference gene, and average $\Delta \mathrm{Ct}$ values of the nifH from the $400 \mu \mathrm{atm} / 25^{\circ} \mathrm{C}$ treatments as a calibrator. Note the different scale on the $y$-axes. $n=3$ for all. Errors are \pm 1 standard deviation.

with maximum fixation occurring approximately $5 \mathrm{~h}$ into the photoperiod (Chen et al., 1998; Berman-Frank et al., 2001a). In agreement with our previous work, elevated $\mathrm{pCO}_{2}$ increased $\mathrm{N}_{2}$ fixation rates, although no significant changes were observed between the low and ambient $\mathrm{pCO}_{2}$ acclimations (250 $\mu \mathrm{atm}$ and $\left.400 \mu \mathrm{atm} p \mathrm{CO}_{2}\right)$ (Levitan et al., 2007). The increase in temperature did not significantly increase $\mathrm{N}_{2}$ fixation rates. During the peak of $\mathrm{N}_{2}$ fixation ( $5 \mathrm{~h}$ into the photoperiod), fixation rates increased from values of $4-7 \mathrm{nmol} \mathrm{N} \mathrm{\mu g} \mathrm{chl}{ }^{-1} \mathrm{~h}^{-1}$ at the low and ambient $p \mathrm{CO}_{2}$ acclimations (250 $\mu$ atm and $400 \mu$ atm $p \mathrm{CO}_{2}$ ) to $15-20 \mathrm{nmol} \mathrm{N}_{2} \mu \mathrm{g} \mathrm{chl}^{-1} \mathrm{~h}^{-1}$ for both $900 \mu$ atm acclimations.

In Azotobacter vinelandii, each dinitrogenase unit can fix $1 \mathrm{~N}_{2}$ to $2 \mathrm{NH}_{4}{ }^{+}$in $1.5 \mathrm{~s}$ (Vichitphan, 2001). Based on the similarity between Trichodesmium's nitrogenase and that of Azotobacter vinelandii (Zehr et al., 1997), we expressed this turnover time, under an assumption of a cellular stoichiometry of $6 \mathrm{NifH}: 2 \mathrm{NifDK}$, as measured in Gloeothece strain ATCC 27152 (Reade et al., 1999). Using this stoichiometry of $6 \mathrm{NifH}: 2 \mathrm{NifDK}$, the minimum reaction rate can be expressed as of $0.44 \mathrm{NH}_{4}{ }^{+} \mathrm{S}^{-1} \mathrm{NifH}^{-1}$. An alternate assumption of the minimum stoichiometry of 4NifH:2NifDK, based on enzyme structural data that reveal two docking sites for the Fe protein on the FeMo protein, generates a maximum reaction rate of $0.67 \mathrm{NH}_{4}^{+}$ $\mathrm{S}^{-1} \mathrm{NifH}^{-1}\left[1 \mathrm{~N}_{2}\right.$ to $\left.2 \mathrm{NH}_{4}^{+} 1.5 \mathrm{~s}^{-1}(2 \mathrm{NifH})^{-1}\right]$. These alternative values are indicated with dotted lines in Fig. 5 to show an approximate range for potential nitrogenase reaction rates (Fig. 5).

We then normalized $\mathrm{N}_{2}$ fixation rates to $\mathrm{NifH}$ protein abundance to estimate $\mathrm{NifH}$ apparent reaction rates (Fig. 5), and compared these calculated rates to the range of the potential nitrogenase reaction rates. By doing so, we assumed a constant Fe protein : FeMO protein ratio, based on the range provided by Reade and colleagues (1999). $\mathrm{pCO}_{2}$ concentrations appeared to control the apparent reaction rates with peak $\mathrm{N}_{2}$ fixation in the middle of the light period averaging from 0.42 to $0.47 \mathrm{NH}_{4}^{+} \mathrm{s}^{-1}$ $\mathrm{NifH}^{-1}$ under $900 \mu \mathrm{atm} p \mathrm{CO}_{2} 31^{\circ} \mathrm{C}$ and $25^{\circ} \mathrm{C}$ respectively (Fig. 5). An exception was observed in the $9 \mathrm{~h}$ time point 


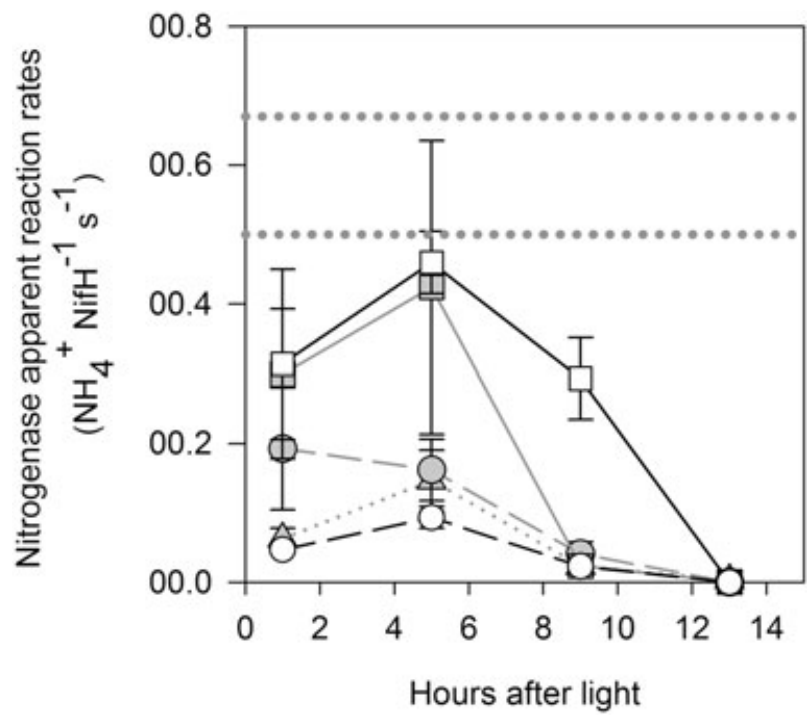

Fig. 5. Temporal changes in the apparent reaction rate of nitrogenase in Trichodesmium IMS101, under a matrix of $\mathrm{pCO}_{2}$ and temperatures. The horizontal region between the dotted lines represents the nitrogenase potential reaction rate range based on published literature from other species, presented for comparison with the apparent reaction rates estimated for Trichodesmium IMS101. Open symbols and black lines are for $25^{\circ} \mathrm{C}$, grey symbols and grey line represent $31^{\circ} \mathrm{C}$. Squares: $900 p \mathrm{pO}_{2}$; circles: $400 \mu \mathrm{atm} p \mathrm{CO}_{2}$; triangles: $250 \mu$ atm $p \mathrm{CO}_{2} . n=3$ for all. Errors are \pm 1 standard deviation.

for $900 \mu \mathrm{atm}$, in which the $25^{\circ} \mathrm{C}$ acclimation exhibited higher $\mathrm{N}_{2}$ fixation rates. Our calculations show that at high $p \mathrm{CO}_{2}$, cultures performed at $\sim 80-100 \%$ of the nitrogenase reaction rates from published literature, while the apparent enzymatic reaction rates for low and ambient $\mathrm{CO}_{2}$ cultures were much lower, ranging from $13 \%$ to $38 \%$ of the nitrogenase reaction rates (taking $0.44-0.67 \mathrm{NH}_{4}^{+}$ $\mathrm{s}^{-1} \mathrm{NifH}^{-1}$ as the nitrogenase potential range).

\section{Transcription patterns}

Our observations (Figs 1-5) show that nitrogen metabolism in Trichodesmium IMS101 is influenced by changes in $\mathrm{pCO}_{2}$ to a much greater extent than by the 6 degree temperature increase. Accordingly, we extended the experiments presented in Fig. $3 \mathrm{~A}$ and examined in detail the diel expression of several key genes in cultures growing under $400 \mu \mathrm{atm} / 25^{\circ} \mathrm{C} p \mathrm{pO}_{2}$ and under $900 \mu \mathrm{atm}$ $/ 25^{\circ} \mathrm{C} p \mathrm{CO}_{2}$ (Fig. 4) using RT-qPCR. Transcripts were obtained from matched primer pairs designed for nifH, psbA, glnA, hetR (Fig. 4D) and psaB (Table 1).

Our results show that Trichodesmium IMS101 cultures, grown for several months under elevated $p \mathrm{CO}_{2}$, changed their mRNA expression patterns for several key genes involved in nitrogen metabolism and photosynthesis. The differences between the $p \mathrm{CO}_{2}$ treatments were not reflected in the relative abundance of the genes themselves (using average of nifH at $400 \mu$ atm as a calibrator), resulting in the same enrichment factors for each gene under both $p \mathrm{CO}_{2}$ levels (Fig. 4A-E). However, when comparing the relative abundance among the five genes, it is noticeable that while the transcript abundance of nifH, $p s b A$ and $p s a B$ (Fig. $4 \mathrm{~A}, \mathrm{~B}$ and $\mathrm{E}$ ) is similar, the relative abundance of hetR and $g \ln A$ (Fig. $4 \mathrm{C}$ and $\mathrm{D}$ ) is $1-2$ and 3-4 orders of magnitude lower, respectively (Fig. 4, note the differences in the $y$ axes scale). Although sampled from two independent experiments, the nifH transcript patterns shown in Figs $3 \mathrm{~A}$ and $4 \mathrm{~A}$ correspond to the same time points and show similar trends.

Typically, and in agreement with previous studies at ambient $p \mathrm{CO}_{2}$ (i.e. Chen et al., 1999), levels of all the transcripts remained relatively low from $0-3 \mathrm{~h}$ after the onset of light at $400 \mu$ atm $p \mathrm{CO}_{2}$. From $3 \mathrm{~h}$ after light induction, the transcript levels increased, with specific peaks for each gene. The first gene transcript to peak was nifH at $6 \mathrm{~h}$ after the onset of light (Fig. 4A), followed by $p s b A$ at $9 \mathrm{~h}$ (Fig. 4B) and $g \ln A$ and $p s a B$ at $12 \mathrm{~h}$ after light (Fig. $4 \mathrm{C}$ and E). nifH, $p s b A$ and $p s a B$ exhibited additional peaks. nifH peaked again $3 \mathrm{~h}$ before the onset of light, while the $p s B a$ and $p s a B$ transcripts increased slightly $6 \mathrm{~h}$ before light. At $900 \mu \mathrm{atm} p \mathrm{CO}_{2}$ nifH, $p s b A$ and $g \ln A$ transcript levels (Fig. $4 \mathrm{~A}-\mathrm{C}$ ) increased at the start of the photoperiod and peaked concurrently $3 \mathrm{~h}$ into the photoperiod. At this $p \mathrm{CO}_{2}$ acclimation, hetR and psaB transcript levels were highest towards the beginning of the dark phase and were relatively steady throughout the dark phase (Fig. 4D and E). Thus, when comparing both growth conditions, the main impact of acclimation at $900 \mu$ atm $p \mathrm{CO}_{2}$ was a more synchronized expression of all genes tested, with an obvious peak at $3 \mathrm{~h}$ into the photoperiod (Fig. 4A-E).

Table 1. Sequences of forward and reverse primers for five target genes, nifH, glnA, $p s b A, p s a B$ and hetR.

\begin{tabular}{llll}
\hline Gene & Description & Forward primer (5' to $\left.3^{\prime}\right)$ & Reverse primer $\left(5^{\prime}\right.$ to $\left.3^{\prime}\right)$ \\
\hline nifH & Fe protein of nitrogenase & GGTCCTGAGCCTGGTGTAGG & GATAGCAGTAATAATACCACGGCCA \\
glnA & Glutamine synthetase & AATTTGGAAAGACGGAGAGCC & AAATTAGCATAACCATCACCCCAG \\
$p s b A$ & Subunit of photosystem II (D1) & CAGCGGTCGCGTAATCAAT & CATTCCTAAGTAGCGCGGTTAA \\
psaB & Subunit of photosystem I & TCGGATCTGGTATGGAATTGC & CCATCGTGGGTTTCAAAGTCAT \\
hetR & Key regulatory gene in heterocyst differentiation & TTATATAATGGTTGAAGATACAGCTCGC & CCAGTCCTTCATTAACCGGAAA \\
\hline
\end{tabular}

Primers were designed using Primer Express Software v2.0. 


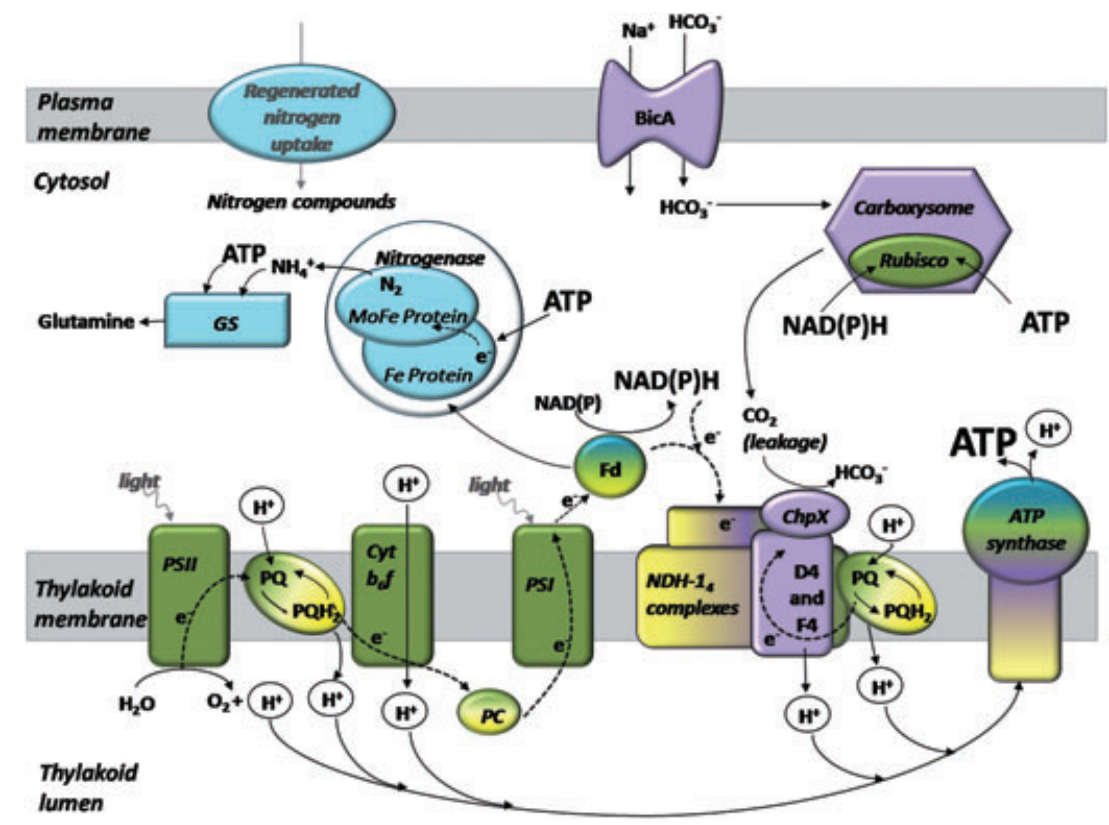

Fig. 6. Schematic representation of major cellular complexes involved in energy flow [electron, ATP, NAD(P)H] and organic skeletons in Trichodesmium IMS101. We suggest that reallocation of energy between these components allows for increased $\mathrm{N}_{2}$ fixation and growth rates elevated high $\mathrm{pCO}_{2}$. BicA and $\mathrm{NDH}-1_{4}$ complexes are after Badger and Price (2003) and Badger and colleagues (2006). Photosynthetic complexes are green, respiratory contribution is marked by yellow, CCM complexes are purple and nitrogen metabolism is represented in blue. The shared metabolic components are indicated by a mix of the respective colours above.

\section{Discussion}

We examined the combined effect of high $\mathrm{pCO}_{2}$ and elevated temperatures on the diazotroph Trichodesmium IMS101 at the transcriptional, translational and enzymatic activity levels. Our results corroborate earlier studies showing enhanced growth (Fig. 1) and $\mathrm{N}_{2}$ fixation rates (Fig. 3C) under higher $\mathrm{pCO}_{2}$ (Hutchins et al., 2007; Levitan et al., 2007; Ramos et al., 2007). Additionally, we show that while higher temperatures combined with elevated $\mathrm{pCO}_{2}$ further stimulated growth rates, nitrogenase activity increased under elevated $p \mathrm{CO}_{2}$, independently of temperature changes (except $9 \mathrm{~h}$ after light, Figs $3 \mathrm{C}$ and 5).

The cellular stoichiometry of carbon and nitrogen reflected in the $\mathrm{C}: \mathrm{N}$ ratios (Fig. $2 \mathrm{~A}$ ) remained relatively stable across all growth conditions tested. $\mathrm{C}: \mathrm{N}$ values approximated the Redfield ratio $(6.53 \pm 0.75, n=61)$ and corresponded with published studies (Berman-Frank et al., 2001b; LaRoche and Breitbarth, 2005; Küpper et al., 2008), including studies showing the effects of $\mathrm{pCO}_{2}$ on Trichodesmium (Hutchins et al., 2007; Levitan et al., 2007; Ramos et al., 2007; Kranz et al., 2009). The relatively stable $\mathrm{C}: \mathrm{N}$ ratios at different $p \mathrm{CO}_{2}$ levels, combined with the apparent constancy in photosynthetic rates (Levitan et al., 2007; Kranz et al., 2009), suggest that net nitrogen and carbon accumulation in the cell remains proportional under both ambient $(400 \mu \mathrm{atm})$ and high $(900 \mu \mathrm{atm}) \quad \mathrm{pCO}_{2}$. For exponentially growing Trichodesmium NIBB1067 cultures (another strain of $T$. erythraeum), under comparable conditions, $\mathrm{N}_{2}$ fixation accounted for only $14-16 \%$ of the gross daily $\mathrm{N}$ uptake, under comparable conditions (Mulholland et al., 1999).
Hence, growth under elevated $p \mathrm{CO}_{2}$ may increase the fraction of assimilated organic nitrogen generated by $\mathrm{N}_{2}$ fixation (per day), rather than change the net amount of cellular nitrogen accumulated in the cell.

In contrast with the relative stability found for carbon and nitrogen, Trichodesmium spp. exhibit highly flexible phosphorus quotas. Trichodesmium IMS101 C:N : P ratios may reach $\mathrm{C}_{(585 \pm 56)}: \mathrm{N}_{(90 \pm 10)}: \mathrm{P}_{(1)}$ (White et al., 2006), with a plasticity in the $N: P$ ratio that ranges between 11:1 and 125:1 (Krauk et al., 2006). Ratios close to the Redfield ratio were achieved when growing in $P$ replete media, probably due to phosphorus luxury uptake (White et al., 2006). Our results demonstrate higher C : P in Trichodesmium IMS101 grown at enhanced temperatures and higher $p \mathrm{CO}_{2}$ (Fig. 1). This suggests that less $\mathrm{P}$ is required for supporting higher $\mathrm{N}_{2}$ fixation and growth rates in Trichodesmium IMS101 under 'greenhouse' conditions.

What mechanisms can account for the stoichiometric stability of carbon and nitrogen, yet enable higher $\mathrm{N}_{2}$ fixation rates, elevated $\mathrm{C}: \mathrm{P}$, and increased growth rates under the predicted temperatures and elevated $\mathrm{pCO}_{2}$ ? We explored protein abundance and mRNA transcript levels to understand the regulation of nitrogen metabolism. We focused on two important protein subunits, $\mathrm{NifH}$ (nitrogenase Fe protein) and GInA (a subunit of glutamine synthetase) that assimilates the recently fixed $\mathrm{NH}_{4}{ }^{+}$to organic compounds via the GS/GOGAT pathway. The mobile subunit of the nitrogenase, the Fe protein (Fig. 6), functions as a link between the metabolic electron donors (Fd, NADPH) and the $\mathrm{N}_{2}$ reducing subunit, the MoFe protein (Zehr et al., 1997; Raymond et al., 2004). The $\mathrm{NH}_{4}{ }^{+}$generated via nitrogenase is volatile and toxic and 
so GS activity closely follows nitrogenase activity (Mulholland and Capone, 2000). For all $p \mathrm{CO}_{2}$ /temperature combinations, the $\mathrm{NifH}$ abundance (pmol $\mu \mathrm{g}$ protein $^{-1}$ ) was similar during the peak of $\mathrm{N}_{2}$ fixation (Fig. 3b). GlnA subunit abundance was also stable during the day and across treatments (data not shown).

While NifH and GInA protein pools did not notably change between treatments, we attempted to calculate an estimated reaction rate for nitrogenase (Fig. 5). Based on our assumptions and calculations, higher $\mathrm{pCO}_{2}$ can increase the estimated nitrogenase reaction rates (Fig. 5). This may indicate differential sensitivity of enzymatic function to environmental conditions. While elevated $\mathrm{pCO}_{2}$ may enable higher enzymatic activities that are closer to the published potential nitrogenase reaction rates for other prokaryotes, the experimental range of temperatures here does not seem to affect it.

We observed that at $400 \mu \mathrm{atm} g \ln A$ transcripts increased during the light phase and reached maximum levels before the end of the photoperiod, $6 \mathrm{~h}$ after the peak in nifH transcripts abundance (Fig. 4A and 4C). This corresponds with previous observations done on field samples of Trichodesmium thiebautii demonstrating two peaks of GS mRNA transcript abundance, one before dawn (that we did not observe) and the second during late afternoon (Kramer et al., 1996). The diel changes in GInA transcripts, combined with the relatively small changes in GS activity (Mulholland and Capone, 1999), led to the assumption that Trichodesmium spp. possess two GS pools, one of which is a nitrogenase linked pool (Mulholland and Capone, 2000). If the catalytic rate of the GS could be shown to increase under $900 \mu \mathrm{atm}$, the increase in the apparent nitrogenase reaction rates (Fig. 5) could further support the assumption that these two enzymes are co-regulated (Flores and Herrero, 1994).

The limited changes in cellular stoichiometry of $\mathrm{C}: \mathrm{N}$, the parallel change in $\mathrm{C}: \mathrm{P}$ ratios and the calculated increased catalytic efficiencies under high $\mathrm{pCO}_{2}$ led us to further examine the idea of changes in energy allocations of $\mathrm{ATP}, \mathrm{NAD}(\mathrm{P}) \mathrm{H}$, electrons and organic skeletons. In cyanobacteria, including Trichodesmium, the metabolic pathways and the cellular currencies (as above) are shared among photosynthesis and CCM, respiration, and nitrogen metabolism (Fig. 6). Based on published literature and our results we suspect that the molecular to physiological changes observed under elevated $\mathrm{pCO}_{2}$ and temperatures (Figs 1-5) are due to reallocations of these cellular currencies that are environmentally regulated (Fig. 6).

Previously, we hypothesized that changes in $\mathrm{pCO}_{2}$ will influence photosynthetic rates. However, photosynthetic rates were not significantly modified by $\mathrm{pCO}_{2}$ (Levitan et al., 2007; Kranz et al., 2009). Therefore, we suggested that high $\mathrm{pCO}_{2}$ lowers the dependence of Trichodesmium
IMS101 on energetically expensive active $\mathrm{Ci}$ uptake through CCM (Levitan et al., 2007). This allows for greater allocation of ATP, reducing power, and substrates for $\mathrm{N}_{2}$ fixation and subsequent growth.

While $\mathrm{CO}_{2}$ is the substrate for RubisCo, many cyanobacteria, including diazotrophs, have carbon concentrating mechanisms (CCM) that enable active uptake and concentration of $\mathrm{CO}_{2}$ or $\mathrm{HCO}_{3}^{-}$, increasing $\mathrm{CO}_{2}$ concentrations near RubisCo. Trichodesmium IMS101 has only a partial suite of CCM genes (Badger et al., 2006). The genes found encode proteins for carboxysomes, homologues of a low affinity high flux $\mathrm{HCO}_{3}{ }^{-}$transporter, BicA and a low affinity $\mathrm{CO}_{2}$ uptake complex, $\mathrm{NDH}-1_{4}$, while lacking homologues for inducible high affinity $\mathrm{Ci}$ uptake systems (Badger et al., 2006). A 'true' functional internal carbonic anhydrase (iCA), required to convert between $\mathrm{CO}_{2}$ and $\mathrm{HCO}_{3}{ }^{-}$, was never found, not in genetic analysis (Badger et al., 2006), nor in lab experiments (S. Kranz and O. Levitan, unpubl. data). The only published study directly measuring CCM activity in Trichodesmium (Kranz et al., 2009) demonstrated that Trichodesmium IMS101 grown at different $\mathrm{pCO}_{2}$ levels uses $\mathrm{HCO}_{3}{ }^{-}$for over $90 \%$ of its DIC uptake, probably via the BicA complex (Fig. 6). Moreover, elevated $\mathrm{pCO}_{2}$ resulted in a decrease in the cellular affinity to total DIC but not in the carboxylation efficiency of RuBisCo (Kranz et al., 2009).

Although principally a bicarbonate user, Trichodesmium IMS101 possesses $\mathrm{NDH}-1$ dehydrogenase $\left(\mathrm{NDH}-1_{4}\right)$. The $\mathrm{NDH}-1_{4}$ is restricted to the thylakoid membrane in cyanobacteria (Ohkawa et al., 2001; Badger et al., 2006, Fig. 6) and is probably involved in the hydration that converts $\mathrm{CO}_{2}$ to $\mathrm{HCO}_{3}$ (Price and Badger, 2002). This provides further evidence linking CCM to both photosynthetic and respiratory electron chains and to the thylakoid membrane potential (Fig. 6). Neither BicA nor NDH-1 ${ }_{4}$ directly consumes ATP (Badger et al., 2006). Yet, BicA is strongly dependent on photosynthetic electron flow required to maintain the transmembrane potential that drives the $\mathrm{Na}^{+} /$ $\mathrm{HCO}_{3}{ }^{-}$exchange (Kranz et al., 2009, S. Kranz and O. Levitan, unpubl. data and Fig. 6), while $\mathrm{NDH}-1_{4}$ is coupled to electron flow (Badger and Price, 2003).

$\mathrm{NADPH}$ and reduced ferredoxin (Fd, Fig. 6) can act as potential electron donors for both $\mathrm{NDH}_{-} 1_{4}$ and nitrogenase Fe protein. We propose that more efficient proton pumping into the thylakoid lumen via the $\mathrm{NDH}-1_{4}$ may be possible through coupling with $Q$ cycle activity (Badger and Price, 2003; Milligan et al., 2007), thereby improving the energetics of $\mathrm{CO}_{2}$ conversion. This can increase the membrane potential and will contribute to the amount of ATP generated by the ATP synthase (Fig. 6). Additionally, lowering the CCM demand for electrons, i.e. via lower affinity to DIC (Kranz et al., 2009), can thereby allow larger electron flux to nitrogenase (Fig. 6). This would 
result in an increased electrons flux available for the $\mathrm{Fe}$ protein, which could enable increased $\mathrm{N}_{2}$ fixation rates in areas of limited Fe availability.

Nitrogenase requires at least 16 molecules of ATP to fix one molecule of $\mathrm{N}_{2}$ into two $\mathrm{NH}_{3}$ (Postgate, 1998). The Fe protein carries electrons from Fd or NADPH and delivers it to the MoFe subunit, performing a docking, electron transfer, ATP hydrolysis, detach cycle (Hageman and Burris, 1978). Binding of ATP to the Fe protein of the nitrogenase complex $(\mathrm{NifH})$ is essential for the transfer of electrons to the MoFe protein (Hageman and Burris, 1978). The release of the $\mathrm{NifH}$ subunit from the MoFe complex, thought to be the rate limiting step in $\mathrm{N}_{2}$ fixation (Vichitphan, 2001), occurs after the hydrolysis of the bound ATP. ATP could therefore be a limiting substrate for $\mathrm{N}_{2}$ fixation under 400 and $250 \mu \mathrm{atm} p \mathrm{CO}_{2}$.

For nitrogenase, the ATP consumption : electron transfer ratio increases under conditions of nitrogenase enzyme inhibition (Lanzilotta and Seefeldt, 1996; Vichitphan, 2001). At favourable conditions, such as growth at $900 \mu$ atm $p \mathrm{CO}_{2}$, the overall ATP requirement per $\mathrm{NH}_{4}{ }^{+}$ generated may decrease (Fig. 6). This could also lead to higher rates of $\mathrm{N}_{2}$ fixation per nitrogenase, without any substantial changes in the abundance of the nitrogenase Fe subunit (Fig. 3B and C). Lower ATP and Fe requirement per unit of $\mathrm{N}_{2}$ fixation under elevated $p \mathrm{CO}_{2}$ could thus enable increased $\mathrm{N}_{2}$ fixation and growth in areas of limited $\mathrm{Fe}$ availability such as found in many oceanic areas (Berman-Frank et al., 2001b; Mills et al., 2004). We therefore propose that acclimation to 'greenhouse' conditions allows for more effective resource utilization.

Transcript abundance does not necessarily directly correspond to protein pools, which in turn can be offset from enzyme activity. Modulation of nitrogenase activity has also been ascribed to a modification of the $\mathrm{NifH}$ protein that correlates with a loss of activity late in the light period, following the period of maximum fixation rates (Capone et al., 1990; Zehr et al., 1993; Chen et al., 1998). The large increase in $\mathrm{N}_{2}$ fixation rates at midday (Fig. $3 \mathrm{C}$ ) does not correspond with changes in abundance of the $\mathrm{NifH}$ protein between the different treatments (Fig. 3B). This may result from either post-translational regulation of the enzyme (i.e. as suggested in Fig. 5) or differences in the abundance of other subunits. Transcription initiation, proteolysis and post-translational modification of the nitrogenase Fe protein could regulate $\mathrm{N}_{2}$ fixation in Trichodesmium IMS101. Although nifHDK operon is likely transcribed as a single unit (Dominic et al., 1998), transcription termination upstream of nifD, a longer half life of the nifH transcript (Chen et al., 1998) or different rates of translation, could result in differential expression of the nitrogenase proteins. Trichodesmium IMS101 possesses a circadian clock that controls the expression of the nitrogenase operon and regulates metabolic functions (Chen et al., 1998). Yet, the signal that triggers and controls nifHDK gene transcription may be indirect (Chen et al., 1998), for example a change in $\mathrm{pCO}_{2}$.

We demonstrate that elevated $p \mathrm{CO}_{2}$, regardless of temperature, impacts transcripts of several genes and protein activity in Trichodesmium IMS101. Although the $\mathrm{pCO}_{2}$ level did not change the relative transcript abundance of the five genes (Fig. 4, note the differences in $\mathrm{y}$ axes scales), increased $p \mathrm{CO}_{2}$ altered nifH transcript expression patterns (Fig. 4A) and caused an earlier ( $3 \mathrm{~h}$ after light) peak. This peak was synchronized with the peaks of $p s b A$ and $g \ln A$ (Fig. 4B and C), and to a lower extent also with hetR (Fig. 4D). The relative transcript abundance of the $g \ln A$ and hetR was kept notably lower at both $\mathrm{pCO}_{2}$ (Fig. 4C and D). This corresponds with a fourfold lower abundance of the GInA protein, of glutamine synthetase, relative to the $\mathrm{NifH}$ protein (data not shown).

Utilizing different cellular and mechanistic strategies could enable higher $\mathrm{N}_{2}$ fixation and increased growth rates under high $\mathrm{pCO}_{2}$ and temperatures. One strategy is the balance between stoichiometric stability in carbon and nitrogen and the plasticity in $\mathrm{P}$ and $\mathrm{Fe}$ quotas (Berman-Frank et al., 2001b; 2007; White et al., 2006; Küpper et al., 2008). Phosphorus is a fundamental cellular building block required for ATP, for nucleic acid biosynthesis, and in mediation of post-translational modification that is essential for gene regulation (Scanlan and Wilson, 1999). We suggest that elevated $\mathrm{pCO}_{2}$ allows for lower $\mathrm{P}$ quotas and reduced bioenergetic demands, i.e. $\mathrm{CCM}$, relative to $\mathrm{C}$ (Fig. $2 \mathrm{~B}$ ). This, in turn, can enable higher $\mathrm{N}_{2}$ fixation and increased growth rates (Figs 1 and $3 C)$. A second strategy for achieving higher growth rates is to lower the energetic investment in building protein complexes. If verified, an increase in the apparent reaction rates of nitrogenase (Fig. 5) and possibly GS, with no increase in $\mathrm{NifH}$ protein (Fig. 3B) or GInA amount (data not shown), could account as an example for this strategy at higher $\mathrm{pCO}_{2}$.

Trichodesmium is an ancient diazotrophic cyanobacterium that evolved during the Archaean (Berman-Frank et al., 2001a) and thrives in the present oceans, forming huge blooms easily observed by satellites over the subtropical and tropical oceans (Capone et al., 1997; Capone and Subramaniam, 2005). Trichodesmium's arsenal of cellular and mechanistic strategies, including the combination of energy reallocation (Fig. 6), flexibility of the CCM operation (Kranz et al., 2009, S. Kranz and O. Levitan, unpubl. data) and $P$ stoichiometry (Fig. 2) together with possible improved enzymatic efficiency (Figs $3 \mathrm{C}$ and 5), will enable higher $\mathrm{N}_{2}$ fixation and growth at higher $\mathrm{pCO}_{2}$ and temperatures, while requiring less $\mathrm{P}$, and possibly less Fe, per $\mathrm{C}$. We suggest that this will extend Trichodesmium's potential niche and allow the persistence and dominance of this cyanobacterium in the future oceans, 
including tropical areas where it is presently scarce (Church et al., 2008; Bonnet et al., 2008; 2009).

\section{Experimental procedures}

\section{Culturing and growth}

Trichodesmium IMS101 stock cultures were grown in YBCII medium (Chen et al., 1996) at $25^{\circ} \mathrm{C}, 12: 12$ light/dark cycle at $\sim 80 \mu \mathrm{mol}$ photons $\mathrm{m}^{-2} \mathrm{~s}^{-1}$ white light and near future ambient $p \mathrm{CO}_{2}$ concentrations of $400 \mu \mathrm{atm} p \mathrm{CO}_{2}$. Diluted batch cultures were grown in sterile square $1 \mathrm{~L}$ Nalgene bottles as single filaments with gentle bubbling that was sufficient to prevent formation of aggregates but did not cause high turbulence that could harm the integrity of the filaments. Stock cultures were unialgal and under exponential growth the bacterial biomass was negligible and was not observed under light microscopy.

For experiments, cultures were enriched with the appropriate air and $\mathrm{CO}_{2}$ mix for at least 1.5-2 months by bubbling. While acclimation time changes for different species, it is generally assumed that growth under the required conditions for $>10$ generations of growth are sufficient (Maclntyre and Cullen, 2005).

We applied the following $p \mathrm{CO}_{2}$ concentrations: $\sim 250 \mu$ atm (pre-industrial $\mathrm{pCO}_{2}$ concentration), $\sim 400 \mu \mathrm{atm}$ (near future ambient) $\mathrm{pCO}_{2}$ and $\sim 900 \mu \mathrm{atm}$ (expected 2100) $\mathrm{pCO}_{2}$ level. The temperatures used for the experiments were $25^{\circ} \mathrm{C}$ and $31^{\circ} \mathrm{C}$. Acclimation of stock culture to the experimental temperatures was done by a gradual increase of $1^{\circ} \mathrm{C}$ a week. The $\mathrm{pCO}_{2}$ input to the cultures was continuously monitored using an EMP-SB4-TX $\mathrm{CO}_{2}$ gas analyser (Emproco, Ashkelon, Israel). The $400 \mu \mathrm{atm} / 25^{\circ} \mathrm{C}$ treatment was our control since the current ambient $\mathrm{pCO}_{2}$ in the atmosphere in oceanic regions is $\sim 400 \mu \mathrm{atm}$ and $25^{\circ} \mathrm{C}$ is within the range of temperature distribution for natural populations of Trichodesmium spp. $\left(20-30^{\circ} \mathrm{C}\right)$ found in the environment. Growth rates were determined on the basis of chlorophyll a $\left(\mu \mathrm{g} \mathrm{ml}^{-1}\right)$. Biomass was kept under $0.2 \mu \mathrm{g} \mathrm{chl} \mathrm{ml} \mathrm{m}^{-1}$, thereby maintaining a low enough biomass that did not additionally influence the carbonate chemistry of the experimental setup.

\section{Chlorophyll a}

Cultures were collected on GF/F filters and chlorophyll a was extracted by boiling for $6 \mathrm{~min}$ in $90 \%$ methanol and analysed spectrophotometrically at $664 \mathrm{~nm}$ according to Tandeau De Marsac and Houmard (1988).

\section{$N_{2}$ fixation}

$\mathrm{N}_{2}$ fixation rates were determined using the standard acetylene reduction assay (Capone, 1993). Cultures aliquots were spiked with acetylene ( $20 \%$ of headspace volume) and incubated for $2 \mathrm{~h}$. Ethylene production was determined on an SRI 310 flame ionization detector (FID)-GC and converted to $\mathrm{N}$ equivalents assuming a stoichiometry of $4: 1 \quad \mathrm{C}_{2} \mathrm{H}_{4}: \mathrm{N}_{2}$ (Capone and Montoya, 2001). Samples of $6.5 \mathrm{ml}$ culture were incubated for $2 \mathrm{~h}$ in $15 \mathrm{ml}$ gas tight vials that were later filtered for chlorophyll a determination. Chlorophyll a per cell did not change significantly between treatments and therefore the results were normalized to chlorophyll $a$.

\section{Elemental stoichiometry}

Samples of acclimated, exponentially growing cultures, were taken during 4 time points along the day $(1,5,9$ and $13 \mathrm{~h}$ after the onset of light) and filtered onto precombusted $13 \mathrm{~mm}$ GF/F filters. After sampling, the samples were kept in pre-combusted aluminum foil at $-20^{\circ} \mathrm{C}$ and later dried for $24 \mathrm{~h}$ at $60^{\circ} \mathrm{C}$. Analysis was done using an elemental soil analyser with a thermo conductivity detector (NC 2110, hermoQuest, Waltham, MA, USA) for measuring $\mathrm{C}$ and $\mathrm{N}$.

Particulate $\mathrm{P}$ was measured following a modified version of the ALOHA protocol (Hawaii Institute of Marine Biology, Analytical Services laboratory at the University of Hawaii). The method relies on the release of organically bound $P$ compounds as orthophosphate, by high-temperature and pressure combustion. The released orthophosphate reacted with a mixed reagent containing sulfuric acid, molybdic acid and trivalent antimony to form phosphomolybdic acid. The solution was reduced to a blue molybdenum complex by ascorbic acid in the mixture, which was then measured spectrophotometrically $(880 \mathrm{~nm})$ and calculated using a 12 points standard curve.

\section{Sample collection for protein and RNA}

Samples of Trichodesmium IMS101 were collected by gentle filtration (in the dark) on polycarbonate filters for both protein (5 $\mu \mathrm{m}$ pore size, $13 \mathrm{~mm}$ diameter filters, Osmonics) and RNA ( $1 \mu \mathrm{m}$ pore size, $25 \mathrm{~mm}$ diameter filters, Osmonics). For both protocols, filtration time was $\sim 1-3 \mathrm{~min}$ (due to the low cultures biomass). Filters were placed in sterile DNase and RNase free centrifuge tubes and put directly into liquid nitrogen until transfer to $-80^{\circ} \mathrm{C}$ for storage. Sampling was done at 4 time points during the diel cycle, 1, 5, 9 and $13 \mathrm{~h}$ after the onset of light for results presented in Figs 3 and 5. For Fig. 4 , sampling was done across a $24 \mathrm{~h}$ cycle, every $3 \mathrm{~h}$ starting from the onset of light.

\section{Total protein extraction and quantification}

Trichodesmium filters were resuspended in $250 \mu \mathrm{l} 1 \times$ denaturing extraction buffer, containing $140 \mathrm{mM}$ Tris base, $105 \mathrm{mM}$ Tris- $\mathrm{HCl}, 0.5 \mathrm{mM}$ ethylenediaminetetraacetic acid (EDTA), 2\% lithium dodecyl sulfate (LDS), 10\% glycerol, $0.1 \mathrm{mg} \mathrm{ml}^{-1}$ PefaBloc SC (AEBSF) protease inhibitor (Roche). Samples were sonicated until thawed with a microtip attachment at a setting of $30 \%$ using a Fisher Scientific Model 100 Sonic Dismembrator. To avoid overheating, samples were then refrozen immediately in liquid $\mathrm{N}_{2}$. Two cycles of freezing followed by thawing by sonication yielded maximal protein extraction with minimal degradation of representative membrane and soluble proteins (Brown et al., 2008). Following disruption, samples were centrifuged for $3 \mathrm{~min}$ at $10000 \mathrm{~g}$ to remove insoluble material and unbroken cells. 
The total protein concentration was measured with a modified Lowry assay (Bio-Rad DC) using bovine gamma globulin as a comparative protein standard.

\section{Target protein quantification}

Total proteins from samples and quantification standards (AgriSera, Sweden) were separated by electrophoresis on 4-12\% acrylamide gradient mini-gels (NuPAGE Bis-Tris gels, Invitrogen) in MES SDS running buffer (Invitrogen) in an XCell Sure-Lock Tank (Invitrogen) at $200 \mathrm{~V}$ for 35-60 min. Following electrophoresis the proteins were transferred to polyvinylidene difluoride (PVDF) membranes pre-wetted in methanol and equilibrated in $1 \times$ transfer buffer (Invitrogen) using the XCell blot module (Invitrogen) for 60-80 min at $30 \mathrm{~V}$. Immediately following transfer, blots were blocked in $2 \%$ ECL Advance blocking reagent (GE Healthcare) in $20 \mathrm{mM}$ Tris, $137 \mathrm{mM}$ sodium chloride $\mathrm{pH} 7.6$ with $0.1 \%(\mathrm{v} / \mathrm{v})$ tween-20 (TBS-T) for $1 \mathrm{~h}$. For detections of NifH and GlnA, primary antibodies (AgriSera, Sweden) were used at a dilution of $1: 40000$ in $2 \% E C L$ advance blocking reagent in TBS-T. Blots were incubated in primary antibody solution for $1 \mathrm{~h}$. Blots were incubated for $1 \mathrm{~h}$ with horseradish peroxidase conjugated rabbit anti chicken secondary antibody (Abcam), diluted to $1: 40000$ in $2 \%$ ECL Advance blocking reagent in TBS-T. Blots were developed with ECL Advance detection reagent according to the manufacturer's instructions. Images of the blots were obtained using a CCD imager (DNR, $\mathrm{M}$-ChemiBIS). Protein levels on immunoblots were quantified using Quantity One software (Bio-Rad). Adjusted volume values were obtained and standard curves were used to estimate the amounts of protein in experimental samples (after Brown et al., 2008).

\section{$R N A$ extraction and reverse transcription $R T-q P C R$}

At each sampling time point $30 \mathrm{ml}$ of culture was filtered over $1 \mu \mathrm{m}, 25 \mathrm{~mm}$ polycarbonate filter and flash frozen in liquid nitrogen. Samples were stored at $-80^{\circ} \mathrm{C}$ until extraction. mRNA was extracted with the RNeasy Plant Mini Kit (Qiagen Cat. 74904). DNase treatment was accomplished with RNase-Free DNase Set (Qiagen Cat. 79254) as well as with TURBO DNA free (Ambion Cat. AM1907) to erase any DNA contamination. RNA concentration was measured with a NanoDrop ND-1000 Spectrophotometer (peqLab Biotechnologie) and quality was tested with $1 \%$ agarose gels. Reverse transcription was conducted with the QuantiTect Reverse Transcription Kit (Qiagen Cat. 205311). RT-qPCR was carried out with Platinum SYBR Green qPCR SuperMixUDG with ROX (Invitrogen Cat. 11744-500) on an ABI PRISM 7000 Sequence Detection System. Primers for five target genes were designed using Primer Express Software v2.0 (Applied Biosystems) and are presented in Table 1. Transcripts were obtained from matched primer pairs designed for nifH (encoding the Fe protein of nitrogenase, Fig. 4A), psbA (encoding the unstable D1 subunit of photosystem II, Fig. 4B), glnA (glutamine synthetase, Fig. 4C), hetR (Fig. 4D) and $p s a B$ (encoding a photosystem I subunit, Fig. 4E) (Table 1). hetR encodes a key element in heterocyst regulation, appears to play an important, although not fully under- stood, metabolic role in non-heterocystous filamentous cyanobacteria especially after nitrogen depletion (Zhang et al., 2009), and is involved in $\mathrm{N}_{2}$ fixation pathway in Trichodesmium (El-Shehawy et al., 2003).

The RT-qPCR results were checked for inaccurate reactions. Results with deficient primer characteristics and with bad efficiencies according to the LinRegPCR software (Ramakers et al., 2003) were removed prior to calculations. Results were calculated using the $2^{-\Delta \Delta C t}$ method used to calculate relative changes in gene expression determined from real-time quantitative PCR experiments, according to Livak and Schmittgen (2001). This method examines the threshold cycle $(\mathrm{Ct})$ and indicates the fractional cycle number at which the amount of amplified target reaches a fixed threshold (Livak and Schmittgen, 2001). The Ct values of the gene of interest (GOI) are normalized first to the 16S rRNA gene, which is used here as the endogenous reference gene for each time point. This results in $\Delta \mathrm{Ct}$ values, which are equal to the differences in thresholds for the GOI and the endogenous reference gene (Livak and Schmittgen, 2001). In time-course experiments, the gene expression is often compared internally by normalization with a calibrator, which can be the time zero point. For Fig. $3 \mathrm{~A}$ we have chosen to use the early morning values of the $400 \mu \mathrm{atm} / 25^{\circ} \mathrm{C}$ samples as a calibrator gene. For Fig. 4 we have chosen the average $\Delta \mathrm{Ct}$ values of the nifH from the $400 \mu \mathrm{atm} / 25^{\circ} \mathrm{C}$ treatments as a calibrator, since we wanted to compare the relative abundance of the different genes, as well as their time dependence. The time-dependent patterns of expression found with the normalization to the mean $\Delta \mathrm{Ct}$ values of the nifH genes showed the same trends as those obtained with the normalization to the initial control time point. Results and statistics are presented according to Bustin and colleagues (2009).

\section{Statistical analysis}

For the growth rate data (Fig. 1), $n=3$ or $n=4$, we used a non-parametric, Kruskal-Wallis Test, for analysing variance between groups $(p<0.05)$. This was further verified using a one-way ANOVA $(p<0.05)$ followed by a Scheffe post hoc test.

Determining the elemental stoichiometric ratios $(n=12-13$ per treatment) differences of the five treatments was done by verifying normal distribution using a Kolmogorov-Smirnoff and by using one-way ANOVA $(p<0.001)$. The ANOVA was followed by a Scheffe post hoc test that yielded $p<0.001$ for $\mathrm{C}: \mathrm{N}$ averages, $\mathrm{p}<0.05$ for $\mathrm{C}: \mathrm{P}$ averages. For all Scheffe post hoc tests, different letters represent significant difference.

\section{Acknowledgements}

This work is in partial fulfillment of the requirements for a PhD thesis for O. Levitan at Bar Ilan University, and was conducted as part of the BMBF-MOST grant 1950 to I.B.F. and J.L.R. We wish to thank Ms Diana Hümmer (IFM-GEOMAR) and Ms. Dina Spungin (BIU) for technical help. Also, we thank Dr Ondrej Prasil (Institute. Microbiology, Trebon, Czech Republic) for analysing our $\mathrm{C}: \mathrm{N}$ samples. Statistical analysis 
was performed with the advice of Dr. Rachel S. LevyDrummer. O. Levitan was supported by a Reiger Fellowship for Environmental Studies and by the Eshkol scholarship from the Israeli ministry of Science, Culture and Sports. C.M. Brown was supported by NSERC.

\section{References}

Badger, M.R., and Price, G.D. (2003) $\mathrm{CO}_{2}$ concentrating mechanisms in cyanobacteria: molecular components, their diversity and evolution. $J$ Exp Bot 54: 609-622.

Badger, M.R., Price, G.D., Long, B.M., and Woodger, F.J. (2006) The environmental plasticity and ecological genomics of the cyanobacterial $\mathrm{CO}_{2}$ concentrating mechanism. $J$ Exp Bot 57: 249-265.

Berman-Frank, I., Lundgren, P., Chen, Y.B., Kupper, H., Kolber, Z., Bergman, B., and Falkowski, P. (2001a) Segregation of nitrogen fixation and oxygenic photosynthesis in the marine cyanobacterium Trichodesmium. Science 294: 1534-1537.

Berman-Frank, I., Cullen, J.T., Shaked, Y., Sherrell, R.M., and Falkowski, P.G. (2001b) Iron availability, cellular iron quotas, and nitrogen fixation in Trichodesmium. Limnol Oceanogr 46: 1249-1260.

Berman-Frank, I., Quigg, A., Finkel, Z.V., Irwin, A.J., and Haramaty, L. (2007) Nitrogen fixation strategies and Fe requirements in cyanobacteria. Limnol Oceanogr 52: 2260-2269.

Bonnet, S., Guieu, C., Bruyant, F., Prasil, O., Van Wambeke, F., Raimbault, P., et al. (2008) Nutrient limitation of primary productivity in the Southeast Pacific (BIOSOPE cruise). Biogeosciences 5: 215-225.

Bonnet, S., Biegala, I.C., Dutrieux, P., Slemons, L.O., and Capone, D.G. (2009) Nitrogen fixation in the western equatorial Pacific: rates, diazotrophic cyanobacterial size class distribution, and biogeochemical significance. Global Biogeochem Cycles 23: 1-13.

Breitbarth, E., Oschlies, A., and LaRoche, J. (2007) Physiological constraints on the global distribution of Trichodesmium - effect of temperature on diazotrophy. Biogeosciences 4: 53-61.

Brown, C.M., MacKinnon, J.D., Cockshutt, A.M., Villareal, T.A., and Campbell, D.A. (2008) Flux capacities and acclimation costs in Trichodesmium from the Gulf of Mexico. Mar Biol 154: 413-422.

Bustin, S.A., Benes, V., Garson, J.A., Hellemans, J., Huggett, J., Kubista, M., et al. (2009) The MIQE guidelines: minimum information for publication of quantitative realtime PCR experiments. Clin Chem 55: 611-622.

Capone, D.G. (1993) Determination of Nitrogenase activity in aquatic samples using the acetylene reduction procedure. In Handbook of Methods in Aquatic Microbial Ecology. Kemp, P.F., Sherr, B., Sherr, E., and Cole, J. (eds). New York, NY, USA: Lewis Publishers, pp. 621-631.

Capone, D.G., and Montoya, J.P. (2001) Nitrogen fixation and denitrification. Methods Microbiol 30: 501-515.

Capone, D.G., and Subramaniam, A. (2005) Seeing microbes from space - remote sensing is now a critical resource for tracking marine microbial ecosystem dynamics and their impact on global biogeochemical cycles. ASM News 71: 179-196.
Capone, D.G., Oneil, J.M., Zehr, J., and Carpenter, E.J. (1990) Basis for diel variation in nitrogenase activity in the marine planktonic cyanobacterium Trichodesmium thiebautii. Appl Environ Microbiol 56: 3532-3536.

Capone, D.G., Zehr, J.P., Paerl, H.W., Bergman, B., and Carpenter, E.J. (1997) Trichodesmium, a globally significant marine cyanobacterium. Science 276: 1221-1229.

Carpenter, E.J., and Capone, D.G. (2008) Nitrogen fixation in the marine environment. In Nitrogen in the Marine Environment, 2nd edn. Capone, D., Bronk, D., Mulholland, M., and Carpenter, E. (eds). San Diego, CA, USA: Academic Press, pp. 141-198.

Carpenter, E.J., Bergman, B., Dawson, R., Siddiqui, P.J., Soderback, E., and Capone, D.G. (1992) Glutamine synthetase and nitrogen cycling in colonies of the marine diazotrophic cyanobacteria Trichodesmium spp. Appl Environ Microbiol 58: 3122-3129.

Chen, Y.B., Zehr, J.P., and Mellon, M. (1996) Growth and nitrogen fixation of the diazotrophic filamentous nonheterocystous cyanobacterium Trichodesmium sp IMS 101 in defined media: Evidence for a circadian rhythm. J Phycol 32: 916-923.

Chen, Y.B., Dominic, B., Mellon, M.T., and Zehr, J.P. (1998) Circadian rhythm of nitrogenase gene expression in the diazotrophic filamentous nonheterocystous Cyanobacterium Trichodesmium sp strain IMS101. J Bacteriol 180: 3598-3605.

Chen, Y.B., Dominic, B., Zani, S., Mellon, M.T., and Zehr, J.P. (1999) Expression of photosynthesis genes in relation to nitrogen fixation in the diazotrophic filamentous nonheterocystous cyanobacterium Trichodesmium sp IMS 101. Plant Mol Biol 41: 89-104.

Church, M.J., Bjorkman, K.M., Karl, D.M., Saito, M.A., and Zehr, J.P. (2008) Regional distributions of nitrogen-fixing bacteria in the Pacific Ocean. Limnol Oceanogr 53: 6377.

Davis, C.S., and McGillicuddy, D.J. (2006) Transatlantic abundance of the $\mathrm{N}_{2}$ fixing colonial cyanobacterium Trichodesmium. Science 312: 1517-1520.

Dominic, B., Chen, Y.B., and Zehr, J.P. (1998) Cloning and transcriptional analysis of the nifUHDK genes of Trichodesmium sp. IMS101 reveals stable nifD, nifDK and nifK transcripts. Microbiology-UK 144: 3359-3368.

El-Shehawy, R., Lugomela, C., Ernst, A., and Bergman, B. (2003) Diurnal expression of hetR and diazocyte development in the filamentous non-heterocystous cyanobacterium Trichodesmium erythraeum. Microbiology-Sgm 149: 1139-1146.

Flores, E., and Herrero, A. (1994) Assimilatory nitrogen metabolism and its regulation. In The Molecular Biology of Cyanobacteria. Bryant, D.A. (ed.). Dordrecht, the Netherlands: Kluwer Scientific Publications, pp. 487-517.

Hageman, R.V., and Burris, R.H. (1978) Kinetic studies on electron-transfer and interaction between nitrogenase components from Azotobacter vinelandii. Biochemistry 17: 4117-4124.

Holl, C.M., and Montoya, J.P. (2008) Diazotrophic growth of the marine cyanobacterium Trichodesmium IMS101 in continuous culture: effects of growth rate on $\mathrm{N}_{2}$ fixation rate, biomass, and C : N : P stoichiometry. J Phycol 44: 929937. 
Hutchins, D.A., Fu, F.-X., Zhang, Y., Warner, M.E., Portune, K., Bernhardt, P.W., and Mulholland, M.R. (2007) $\mathrm{CO}_{2}$ control of Trichodesmium $\mathrm{N}_{2}$ fixation, photosynthesis, growth rates, and elemental ratios: implications for past, present, and future ocean biogeochemistry. Limnol Oceanogr 52: 1293-1304.

Kramer, J.G., Wyman, M., Zehr, J.P., and Capone, D.G. (1996) Diel variability in transcription of the structural gene for glutamine synthetase $(g \ln A)$ in natural populations of the marine diazotrophic cyanobacterium Trichodesmium thiebautii. FEMS Microbiol Ecol 21: 187-196.

Kranz, S., Sültemeyer, D., Richter, K.-U., and Rost, B. (2009) Carbon acquisition by Trichodesmium: the effect of $\mathrm{pCO}_{2}$ and diurnal changes. Limnol Oceanogr 54: 548559.

Krauk, J.M., Villareal, T.A., Sohm, J.A., Montoya, J.P., and Capone, D.G. (2006) Plasticity of N : P ratios in laboratory and field populations of Trichodesmium spp. Aquat Microb Ecol 42: 243-253.

Küpper, H., Ferimazova, N., Setlik, I., and Berman-Frank, I. (2004) Traffic lights in Trichodesmium. Regulation of photosynthesis for nitrogen fixation studied by chlorophyll fluorescence kinetic microscopy. Plant Physiol (Rockville) 135: 2120-2133.

Küpper, H., Setlik, I., Seibert, S., Prasil, O., Setlikova, E., Strittmatter, M., et al. (2008) Iron limitation in the marine cyanobacterium Trichodesmium reveals new insights into regulation of photosynthesis and nitrogen fixation. New Phytol 179: 784-798.

Lanzilotta, W.N., and Seefeldt, L.C. (1996) Electron transfer from the nitrogenase iron protein to the $[8 \mathrm{Fe}-(7 / 8) \mathrm{S}]$ clusters of the molybdenum-iron protein. Biochemistry 35: 16770-16776.

LaRoche, J., and Breitbarth, E. (2005) Importance of the diazotrophs as a source of new nitrogen in the ocean. J Sea Res 53: 67-91.

Levitan, O., Rosenberg, G., Setlik, I., Setlikova, E., Grigel, J., Klepetar, J., et al. (2007) Elevated $\mathrm{CO}_{2}$ enhances nitrogen fixation and growth in the marine cyanobacterium Trichodesmium. Global Change Biol 13: 531538.

Lin, S.J., Henze, S., Lundgren, P., Bergman, B., and Carpenter, E.J. (1998) Whole-cell immunolocalization of nitrogenase in marine diazotrophic cyanobacteria, Trichodesmium spp. Appl Environ Microbiol 64: 3052-3058.

Livak, K., and Schmittgen, T. (2001) Analysis of relative gene expression data using real-time quantitative PCR and the $2^{-\Delta \Delta C t}$ method. Methods 25: 402-408.

MacIntyre, H.L., and Cullen, J.J. (2005) Using cultures to investigate the physiological ecology of microalgae. In Algal Culturing Techniques. Anderson, R.A. (ed.). Burlington, MA, USA: Elsevier Academic Press, pp. 287326.

Mahaffey, C., Michaels, A.F., and Capone, D.G. (2005) The conundrum of marine $\mathrm{N}_{2}$ fixation. Am J Sci 305: 546595.

Milligan, A.J., Berman-Frank, I., Gerchman, Y., Dismukes, G.C., and Falkowski, P.G. (2007) Light-dependent oxygen consumption in nitrogen-fixing cyanobacteria plays a key role in nitrogenase protection. J Phycol 43: 845852.
Mills, M.M., Ridame, C., Davie, M., La Roche, J., and Geider, R.J. (2004) Iron and phosphorus co-limit nitrogen fixation in the eastern tropical North Atlantic. Nature 429: 292-294.

Mulholland, M.R., and Capone, D.G. (1999) Nitrogen fixation, uptake and metabolism in natural and cultured populations of Trichodesmium spp. Mar Ecol Prog Ser 188: 33-49.

Mulholland, M.R., and Capone, D.G. (2000) The nitrogen physiology of the marine $\mathrm{N}_{2}$ fixing cyanobacteria Trichodesmium spp. Trends Plant Sci 5: 148-153.

Mulholland, M.R., Ohki, K., and Capone, D.G. (1999) Nitrogen utilization and metabolism relative to patterns of $\mathrm{N}_{2}$ fixation in cultures of Trichodesmium NIBB1067. J Phycol 35: 977-988.

Ohkawa, H., Sonoda, M., Shibata, M., and Ogawa, T. (2001) Localization of $\mathrm{NAD}(\mathrm{P}) \mathrm{H}$ dehydrogenase in the cyanobacterium Synechocystis sp. strain PCC 6803. J Bacteriol 183: 4938-4939.

Postgate, J.R. (1998) Nitrogen Fixation. Cambridge, UK: Cambridge University Press.

Price, G.D., and Badger, M.R. (2002) Advances in understanding how aquatic photosynthetic organisms utilize sources of dissolved inorganic carbon for $\mathrm{CO}_{2}$ fixation. Funct Plant Biol 29: 117-121.

Ramakers, C., Ruijter, J.M., Deprez, R.H.L., and Moorman, A.F.M. (2003) Assumption-free analysis of quantitative real-time PCR data. Neurosci Lett 339: 62-66.

Ramos, B.J., Biswas, H., Schulz, K., LaRoche, J., and Riebesell, U. (2007) Effect of rising atmospheric carbon dioxide on the marine nitrogen fixer Trichodesmium. Global Biogeochem Cycles 21: 1-6.

Raven, J.A. (1997) Inorganic carbon acquisition by marine autotrophs. Adv Bot Res 27: 85-209.

Raymond, J., Siefert, J.L., Staples, C.R., and Blankenship, R.E. (2004) The natural history of nitrogen fixation. Mol Biol Evol 21: 541-554.

Reade, J.P.H., Dougherty, L.J., Rogers, L.J., and Gallon, J.R. (1999) Synthesis and proteolytic degradation of nitrogenase in cultures of the unicellular cyanobacterium Gloeothece strain ATCC 27152. Microbiology-UK 145: 1749-1758.

Scanlan, D.J., and Wilson, W.H. (1999) Application of molecular techniques to addressing the role of $P$ as key effector in marine ecosystems. Hydrobiologia 401: 149175.

Tandeau De Marsac, N., and Houmard, J. (1988) Complementary chromatic adaptation: physiological conditions and action spectra. In Cyanobacteria. Packer, L., and Glazer, A.N. (eds). San Diego, CA, USA: Academic Press, pp. 318-328.

Tortell, P.D., Rau, G.H., and Morel, M.M.F. (2000) Inorganic carbon acquisition in costal Pacific phytoplankton communities. Limnol Oceanogr 45: 1485-1500.

Vichitphan, K. (2001) Azotobacter vinelandii Nitrogenase: Effect of Amino-acid Substitutions at the $\alpha$ Gln-191 Residue of the MoFe Protein on Substrate Reduction and CO Inhibition. PhD Thesis. Blacksburg, VA, USA: Virginia Polytechnic Institute and State University.

White, A.E., Spitz, Y.H., Karl, D.M., and Letelier, R.M. (2006) Flexible elemental stoichiometry in Trichodesmium spp. and its ecological implications. Limnol Oceanogr 51: 17771790. 
Zehr, J.P., Ohki, K., and Fujita, Y. (1991) Arrangement of nitrogenase structural genes in an aerobic filamentous nonheterocystous cyanobacterium. J Bacteriol 173: 70557058.

Zehr, J.P., Wyman, M., Miller, V., Duguay, L., and Capone, D.G. (1993) Modification of the Fe protein of nitrogenase in Natural populations of Trichodesmium thiebautii. Appl Environ Microbiol 59: 669-676.
Zehr, J.P., Harris, D., Dominic, B., and Salerno, J. (1997) Structural analysis of the Trichodesmium nitrogenase iron protein: implications for aerobic nitrogen fixation activity. FEMS Microbiol Lett 153: 303-309.

Zhang, J.-Y., Chen, W.-L., and Zhang, C.-C. (2009) hetR and patS, two genes necessary for heterocyst pattern formation, are widespread in filamentous nonheterocyst-forming cyanobacteria. Microbiology 155: 1418-1426. 